\title{
FENOMÉN DIFFICULT KNOWLEDGE: JEHO DEFINICE A MOŽNOST UCHOPENÍ V PROSTŘEDÍ MUZEJNÍ EXPOZICE'
}

\section{JANA JIROUTOVÁ}

\section{ABSTRAKT/ABSTRACT:}

Předkládaná studie pojedná o fenoménu difficult knowledge, česky též těžká témata, nabídne jeho definici a vymezení vưči tématům kontroverzním. Během procesu učení zaměřeném na těžká a kontroverzní témata je ve hře celá škála psychických procesů, které kognitivní uchopení tragických historických událostí ovlivňují a v mnohém znemožňují. Nemalou roli zde sehrávají také obecné společensko-politické poměry a převládající konsensus. Studie poodhalí psychologické a pedagogické základy práce $s$ těžkými a kontroverzními tématy a jejich interpretace $v$ muzeu. Upozorní na nesnáze, jež tato témata svírají, a nabídne jeden ze způsobů, kterým je lze překonat a těžká a kontroverzní témata citlivě a důstojně $\mathrm{v}$ prostředí muzejní a galerijní expozice prezentovat.

\section{The difficult knowledge phenomenon: its definition and possible interpretation in a museum display}

The presented study will deal with the phenomenon of difficult knowledge. It will define it and compare it to controversial

1 Příspěvek vznikl na základě výzkumného šetření autorky a byl financován z projektu IGA PdF_2020_031 - Globální narativy ve výtvarné výchově a muzejní a galerijní pedagogice, který byl podpořen Pedagogickou fakultou Univerzity Palackého v Olomouci. topics. When learning difficult knowledge or controversial topics, a whole range of psychological processes are at play, which inform and, in many ways, prevent the cognitive process. General social-political conditions and the prevailing consensus also play an important role here. The study will reveal the psychological and pedagogical foundations of working with difficult knowledge and controversial topics and interpreting them within the museum setting. It will highlight the difficulties they are fraught with and offer one of the ways in which to overcome them in order to present difficult knowledge and controversial topics in a museum or gallery exhibition in the most sensitive and dignified manner.

\section{KLÍČOVÁ SLOVA/KEYWORDS:}

znalost těžkých témat -

kontroverzní témata - krize učení komemorativní muzejní edukace měkká moc muzeí difficult knowledge - controversial topics - learning crisis commemorative museum pedagogy soft power of museums

\section{Úvod}

$\mathrm{V}$ úvodu je třeba připomenout, že interpretace a prezentace difficult knowledge - těžkých témat i témat kontroverzních v expozicích muzejních a galerijních institucí úzce souvisí s fenoménem
https://doi.org/10.5817/MuB2021-1-2

měkké moci ${ }^{2}$ muzea. Měkká moc muzea směřuje $\mathrm{k}$ samé podstatě muzejní instituce a její roli ve společnosti. Míra, v jaké svou měkkou moc daná muzejní či galerijní instituce uplatňuje, podává jistý obraz o její schopnosti či ochotě ovlivňovat mínění široké veřejnosti, konstruovat společenskou a kulturní realitu, utvářet identitu určitých sociálních skupin, legitimizovat všeobecně uznané „pravdy“ a „fakta“ nebo je naopak zpochybňovat a nabízet jiné mnohdy potlačované či upozad’ované pohledy a způsoby vnímání dané problematiky. Uplatňování měkké moci v muzejních a galerijních institucích v konečném důsledku odkazuje $\mathrm{k}$ celospolečenské zodpovědnosti, kterou tyto instituce jako součást občanské společnosti na sebe přebírají a $v$ jejímž rámci usilují o to, aby se aktivně vyjadřovaly $\mathrm{k}$ aktuálním tématům řešeným ve společnosti. Gail Dexter

2 Jak popsal Joseph S. Nye v 80. letech 20. století, soft power neboli měkká moc se v oblasti politologie a mezinárodních vztahů projevuje ,jako způsob, jakým může entita A ovlivnit chování a jednání entity B. Zatímco $v$ př́padě hard power, tedy moci tvrdé, uplatňuje entita $A k$ dosažení svých cílů násilné prostředky anebo finanční motivování, soft power pracuje s přitažlivostí, která je transformována především do oblastí kultury, umění a vzdělávání. Entita A, disponující soft power, tak ovlivňuje a mění preference entity $B$, která zcela dobrovolně, často i nevědomě, mění své chování ve prospěch entity A. Jinými slovy, tam, kde hard power uplatňuje vojenskou sílu a finance, pracuje soft power s myšlenkami, poznatky, hodnotami a kulturou." NYE, Joseph. S. Soft power: the means to success in world politics. New York: Public Affairs, 2004; srov. JIROUTOVÁ, Jana. Muzeum 21. století a využití jeho soft power. In Muzeum a změna $V$. Praha: Asociace muzeí a galerií České republiky, z.s., 2017, s. $150-156$. 


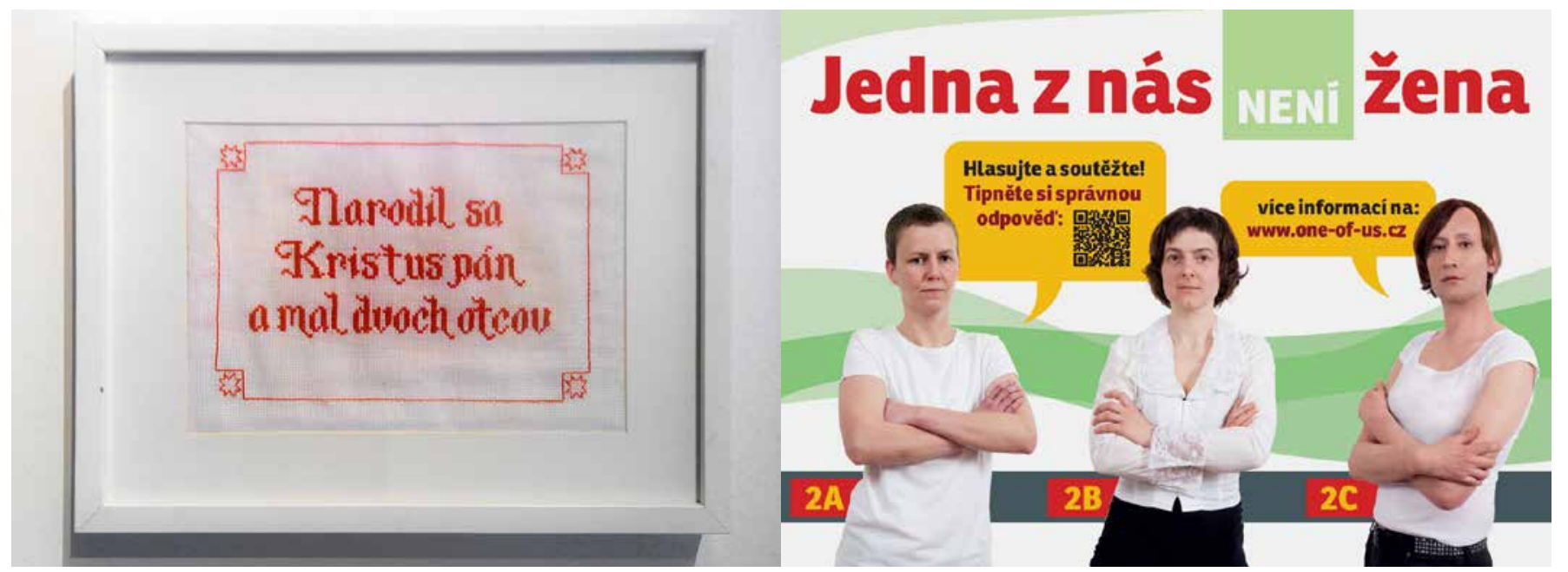

Obr. 1-2: Ukázka děl prezentovaných na výstavě Hate Free? v Centru současného umění DOX v roce 2016, reflektující problémy současné společnosti. Foto Ondřej Moučka (vlevo) a (c)DOX, foto Jan Slavík (vpravo).

Lord a Ngaire Blankenberg považují měkkou moc muzeí a její aktivní využívání za jeden z hlavních faktorů přeměny, jíž prochází základní role muzea od poloviny 20. století a jejímž klíčovým rysem je budovat muzea jako aktivní vzdělávací centra, sloužící široké veřejnosti a podněcující $\mathrm{k}$ multikulturní debatě. ${ }^{3} \mathrm{~A}$ právě proto, aby byla muzea aktuální $a$ aktivně se vyjadřovala $\mathrm{k}$ dění ve společnosti, musí nutně řešit i témata těžká a kontroverzní.

Pro ilustraci, jak lze měkkou moc v muzeích a galeriích uplatňovat, uved'me několik př́kladů z praxe. K aktuálnímu a globálnímu tématu migrace se $\mathrm{v}$ roce 2017 aktivně vyjádřilo newyorské Muzeum moderního umění MoMA, když $\mathrm{v}$ reakci na nové protiimigrační opatření vlády USA, které zakazovalo vstup do USA občanům z vybraných muslimských zemí, znovu vystavilo díla současných umělců pocházejících z Iráku, Iránu, Sýrie apod., čímž symbolicky otevřelo dveře představitelům těchto národů a veřejně deklarovalo svůj postoj.

3 LORD, Gail Dexter a Ngaire BLANKENBERG. Cities, museums and soft power. Washington, DC: American Alliance Of Museums, 2015.
Aktuální téma xenofobie a společného soužití řešila výstava Hate Free? (viz obr. 1-2), kterou $\mathrm{v}$ roce 2016 prezentovalo Centrum současného umění DOX v Praze. Prostřednictvím profesionální i amatérské tvorby a emotivních příběhů výstava odhalovala současné problémy ve společnosti, jakými jsou předsudky, posměch a násilí z nenávisti, kterým je denně vystaveno mnoho našich spoluobčanů na základě své barvy kůže, vyznání, národnosti, sexuální orientace nebo třeba proto, že jsou bez prrístřeší.

Zcela odlišný koncept měla výstava How Much of This is Fiction [Kolik z toho je fikce], kterou v roce 2017 uspořádala liverpoolská organizace FACT, jež své aktivity zaměřuje primárně na podporu a prezentaci umění, které pracuje s novými technologiemi a zkoumá digitální kulturu dneška. Výstavu zaštitovalo fiktivní muzeum Guantanamo Bay Museum of Art and History, které představilo intermediální tvorbu umělců uplatňujících nejrůznější formy mystifikace a klamu. Hlavním zadáním výstavy bylo prezentovat díla, která nevolají po změně, nýbrž návštěvníkům nabízejí alternativní budoucnost, ve které již kýžené změny nastaly (viz obr. 3). V expozici vznikl svět stírající hranice mezi fikcí a realitou, aktivizující návštěvníka a nabádající jej ke kritickým úvahám nad kontroverzními společensko-politickými tématy spojenými mimo jiné s otázkami skrytých mechanismů mocenských struktur a vyplývající z dnešní postpravdivé doby.

\section{K definici pojmu difficult knowledge a rizikům interpretace a prezentace těžkých témat v muzejní expozici}

Deborah Britzman, autorka pojmu difficult knowledge, ${ }^{4}$ jej vnímá jako koncept odkazující jednak $\mathrm{k}$ reprezentaci sociálního traumatu a jednak ke zkušenosti, kterou jednotlivec při zpracovávání těžkého tématu ve výchovněvzdělávacím procesu prožívá. ${ }^{5}$ Přívlastek difficult [těžký] tedy označuje nejen obsahovou stránku daného tématu, ale i podstatu procesu osvojení takového tématu jedincem. Jako vhodný český protějšek k tomuto pojmu se

\footnotetext{
4 Autorka vychází především z anglicky psané odborné literatury a jejího pojmosloví, nebot právě anglo-americký region přináší četné teoretické i metodické podněty.

5 BRITZMAN, Deborah P. Lost subjects, contested objects: Toward a psychoanalytic inquiry of learning. Albany, NY: State University of New York Press, 1998.
} 


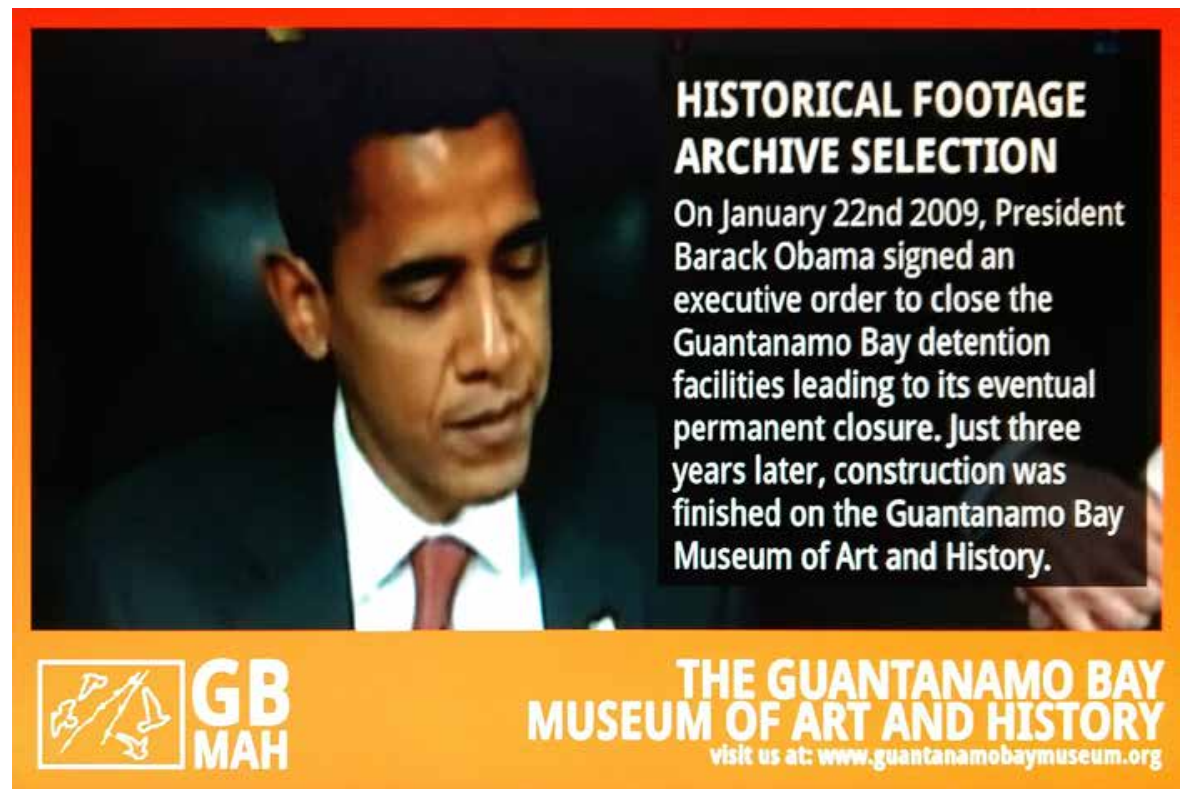

Obr. 3: Ukázka díla fiktivního muzea Guantanamo Bay Museum of Art and History na výstavě How much of this is fiction? prezentované v liverpoolském centru FACT v roce 2017. Fotografie nabízí pohled na fiktivní zprávu o uzavření detenčního tábora v Guantanamo Bay a vytvoření muzea na jeho místě. Foto autorka.

jeví znalost těžkých témat, nebot' reflektuje obě jeho obsahové složky. Julia Rose pracuje s pojmem difficult histories [tragické historické události] a označuje jím různé formy utlačování, násilí a traumat, dokládající schopnost lidské zlovolnosti a krutosti. ${ }^{6}$

Obecně jsou do kategorie těžkých témat zahrnovány takové události, při kterých jsou jiní utlačováni, je na nich pácháno násilí nebo jsou vystavováni traumatizujícím situacím. ${ }^{7}$ Zcela konkrétně se může jednat o masové násilí, otroctví, rasismus, genocidu, válku, šikanu a kyberšikanu, ale též týrání zvířat a jejich nelegální zabíjení.

\section{Oproti tomu témata}

kontroverzní „dávají vzniknout vzájemně sporným výkladům a řešením vycházejícím $\mathrm{z}$ různých alternativních přesvědčení či hodnot a/nebo protichůdných zájmů, a v důsledku toho mají sklon rozdělovat společnost.

6 ROSE, Julia. Interpreting Difficult History at Museums and Historic Sites. Maryland:

Rowman \& Littlefield, 2016.

7 Tamtéž.
Často jde o velmi složitou problematiku, kterou nelze vyřešit pouhým poukázáním na zjevné.“8 Kontroverzní témata zahrnují aktuální problémy a polemiky týkající se otázek politického smýšlení a světonázoru obecně, ale i témat traumatizujících, tedy těžkých. Kontroverzní témata jsou relativně nestálá, často časově a místně podmíněná. ${ }^{9}$ Otázkou je, zda lze takovou proměnlivost sledovat i u témat těžkých. Ta přeci zůstávají těžkými kdekoliv a kdykoliv. Např. téma židovského holocaustu během druhé světové války je celosvětově těžké téma. Ale i toto téma se může stát kontroverzním např. v kontextu politiky holocaustu, kterou popisuje Norman Finkelstein, Peter Novick nebo Pavel Barša. ${ }^{10}$

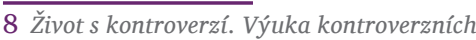
témat prostřednictvím výchovy $k$ demokratickému občanství a lidským právům (EDC/HRE). Praha: Centrum občanského vzdělávání FHS UK, 2017, s. 15.

9 Tamtéž.

10 BARŠA, Pavel. Pamět' a genocida: úvahy o politice holocaustu. Praha: Argo, 2011;

FINKELSTEIN, Norman G. Průmysl holocaustu: úvahy o zneužívání židovského utrpení. Praha: Dokořán, 2006; NOVICK, Peter. The Holocaust in American Life. Boston: Houghton Mifflin Company, 1999. Shodně s Finkelsteinem (2006) a Novickem
Interpretace a prezentace těžkých i kontroverzních témat v muzejní expozici s sebou nese mnoho rizik, která souvisejí nejen s osobností učícího se jedince a jeho psychickým a poznávacím systémem, ale i politickým smýšlením ve společnosti. Na tenký led se mohou při interpretaci takových témat muzea a galerie dostat právě tehdy, kdy jejich interpretace a způsob prezentace daného tématu není v souladu s převládajícím konsensem ve společnosti, kdy takové interpretace rozrušují obecné společenskopolitické poměry, podrývají přijatou ideologii a celkově nezapadají do kolektivní či národní paměti dané historické události. ${ }^{11}$ Muzea

(1999) sleduje Barša (2011) využívání paměti židovského holocaustu z období druhé světové války jako politického nástroje, který vytváří skupinovou identitu a „slouží potrebě sebepotvrzení a prosazení zájmů té či oné partikulární skupiny“. Podle Barši tak vznikla svébytná politika holocaustu, v níž se nacistická genocida Židů nestala „mýtem díky nějaké sobě inherentní kvalitě, ale byla do něj přetvořena zpětně - ve vzpomínce. Nebyly to okolnosti jejího historického času a místa, nýbrž přítomný kontext jejího připomínání, který z ní učinil emblematickou vzpomínku - tedy symbol schopný interpretovat jiné události“. BARŠA, Pavel. Pamět a genocida: úvahy o politice holocaustu. Praha: Argo, 2011, s. 19, 130.

11 ROSE, Julia. Interpreting Difficult History at Museums and Historic Sites. Maryland: Rowman \& Littlefield Publishers, 2016. Pro ilustraci uvádíme př́iklad Jessicy A. Heybach, která popisuje situaci, kdy v rámci předmětu Education as an Agent of Change [Výchova jako nástroj změny] v roce 2008 navštívila se skupinou univerzitních studentů výstavu amerického umělce mexického původu Malaquiase Montoyai, nesoucí název Globalization and War - The Aftermath [Globalizace a válka - důsledky]. Umělec prezentoval realistické fotografie zobrazující týrání vězňů v detenčním táboře Abu Ghraib a neblahé dusledky globalizace a nadnárodní strategie War on Terror [Válka proti terorismu]. Prvotní reakce studentů byly odmítavé a jejich postoje vůči umělci samotnému velmi negativní až útočné. To si vysvětluje Heybach právě tím, že byli konfrontováni s obrazem, který zpochybňoval zahraniční politiku a morální nadřazenost USA, a tudíž nebyl ve shodě s národní identitou země. Heybach tuto skutečnost vysvětlovala tím, že zatímco se všeobecné vzdělávání USA v souladu s panujícím konsensem nezdráhá kriticky posuzovat zločiny proti lidskosti páchané druhými (např. v rámci Holocaust education tedy výchovy o holocaustu Židů za druhé světové války), vlastní válečnou politiku a její důsledky podrobuje kritické reflexi zcela minimálně. Fakt, že téměř každý stát USA má své muzeum židovského holocaustu nebo památník věnovaný jeho obětem, zatímco muzea zaměřená na otroctví dosud existující na území USA bychom spočítali na prstech jedné ruky, tuto 
prezentující takovou interpretaci mohou riskovat i náklonnost zřizovatele, $\mathrm{v}$ důsledku čehož se jim může dostat mimo jiné i menší finanční podpory. ${ }^{12}$

\section{Psychické a pedagogické aspekty fenoménu difficult knowledge}

Proces osvojování těžkých témat stejně tak jako práce s tématy kontroverzními vyvolávají u jedinců různě silné emoční reakce a prožívání. Míra emočního náboje je daná individuálními poznávacími a psychickými strukturami každého jedince. Emoční složka je u těžkých témat přítomna především proto, že jedinec se při setkání s nimi stává svědkem lidského utrpení, traumatu, ${ }^{13}$ což jej nutí revidovat svou dosavadní představu o lidském světě a jeho morálce a přehodnocovat svioj pohled na minulost i přítomnost. ${ }^{14}$

Během osvojování těžkých témat nastává něco, co Jean Piaget označuje jako kognitivní konflikt. Původní představa jedince o lidském světě je v rozporu s novými informacemi a jedinec je tak nucen své dosavadní poznání přehodnocovat, reorganizovat, přetvářet nebo zcela odstraňovat. ${ }^{15}$ Kognitivní konflikt je součástí každého procesu učení a Piaget jej charakterizuje jako základní mechanismus permanentní

skutečnost jenom potvrzuje. HEYBACH, Jessica A. Learning to feel what we see: Critical aesthetics and "difficult knowledge" in an age of war. Critica Questions in Education, 2012, roč. 3, č. 1, s. 23-34.

12 ROSE, Julia. Interpreting Difficult History at Museums and Historic Sites. Maryland: Rowman \& Littlefield Publishers, 2016.

13 Stejně traumatické mohou být i př́rodní katastrofy a zásahy vyšší moci, zanechávající po sobě lidské oběti a materiální škody. Při psychickém zpracování takových událostí, však většinou nedochází ke ztrátě naší představy o lidské morálce a lidském světě plynoucího dle určitého řádu, jehož klíčovým kódem je schopnost rozlišovat mezi dobrem a zlem.

14 ROSE, Julia. Interpreting Difficult History at Museums and Historic Sites. Maryland:

Rowman \& Littlefield, 2016.

15 PIAGET, Jean. Psychologie inteligence. Praha: Portál, 1999. biologické a psychické adaptace organismu na prostředí. Výstupem procesu učení je bud' asimilace, kdy nové informace zapadají do stávající struktury poznání jedince, nebo akomodace, kdy nové informace do stávající poznávací struktury nezapadají a jedinec tak v návaznosti na nově získané informace tuto strukturu reviduje. ${ }^{16}$ Lze tedy vyvodit, že kognitivní konflikt se dostaví pouze tehdy, když nové informace jsou v rozporu s dosavadním poznáním jedince. Čím silnější průběh tento kognitivní konflikt má, tím těžší je cesta $\mathrm{k}$ akomodaci nové informace do stávající poznávací a psychické struktury daného jedince.

Britzman $\mathrm{v}$ této souvislosti hovoři o kognitivní krizi, nebo též krizi učení, kdy jedinec reaguje na novou informaci negativně a $\mathrm{v}$ touze odstranit diskomfort vyvolaný setkáním s těžkým tématem novou informaci nepřijímá. ${ }^{17}$ Jedinec téma vnímá jako nepř́ijemné, lživé, nesmyslné - reaguje odmítavě, vysmívavě, sarkasticky, předpojatě. Jeho pozornost lze snadno odvést jinam, výstavu samotnou zhlédne rychle nebo ji předčasně opouští. Britzman poznamenává, že vzdorování obtížným tématům nemusí nutně vypovídat o nedostatečné informovanosti jedince. Může jít zkrátka o ukazatel toho, že dané téma je pro jedince příliš emočně nabité a on potřebuje delší čas na jeho zpracování. ${ }^{18}$

Vzdorování těžkým tématům mnozí spojují s konceptem loss in learning [ztráta v učení], tedy se ztrátou představy o světě, která již ve světle nových informací neplatí. ${ }^{19}$

\section{Tamtéž.}

17 BRITZMAN, Deborah P. Lost subjects, contested objects: Toward a psychoanalytic inquiry of learning. Albany, NY: State University of New York Press, 1998.

\section{Tamtéž.}

19 BRITZMAN, Deborah P. Lost subjects, contested objects: Toward a psychoanalytic inquiry of

learning. Albany: State University of New York
Shoshana Felman označuje tento vzdor také jako passion for ignorance - vášeň pro neznalost. ${ }^{20}$ Tuto neznalost však nevnímá jako opak vědění. Dle jejích slov vášeň pro neznalost nevypovídá o pasivní absenci vědomostí, nýbrž naopak, jedná se o aktivní a dynamickou negaci, o zanícené odmítání informací. ${ }^{21}$ Moment, kdy u návštěvníka nastává vzdor novým informacím, je dle Felman klíčovým, nebot jeho přesná detekce (lokalizace) nás navede ke konkrétnímu obsahu, s nímž bychom jako učitelé nebo muzejní edukátoři měli dále pracovat. Právě na tento obsah je potřeba se v další práci s návštěvníky zaměřit tak, abychom dosáhli efektivního učení a aby v jeho důsledku mohlo dojít k akomodaci nového poznání do stávající poznávací struktury jedince.

Felman postuluje, že efektivní výuka probíhá právě tehdy, kdy dané téma a otázky, ke kterým téma směřuje, vzbuzují v učících se jedincích alespoň nějaký menší či větší odpor, který je třeba překonat. $^{22}$ Jak dále tvrdí, vzdor nebo otevřené nepřijímání nových informací dává učitelům i muzejním edukátorům prostor pro tolik potřebný dialog, prostřednictvím

Press, 1998; FELMAN, Shoshana. Jacques Lacan and the adventure of insight: Psychoanalysis in contemporary culture. Cambridge and London: Harvard University Press, 1987; PITT, Alice J. Reading Resistance Analytically: On Making the Self in Women's Studies. In ROMAN Leslie G. a Linda EYRE (eds.). Dangerous Territories: Struggles for difference and equality in education. New York, London: Routledge, 1997, s. 127-142. Nahlíženo Freudovou optikou se v reakci na tuto ztrátu v psychice jedince spouští obranné mechanismy, mezi které se řadí například represe (vytěsnění - tedy psychický proces, při kterém dochází k potlačování vnitřních konfliktů do nevědomí) a vzdor těžkým tématům lze pak chápat jako reakci ega jedince, které tak usiluje o své zachování. FREUD, Sigmund. Spisy z let 1913-1917. Praha: Psychoanalytické nakladatelství, 2002.

20 FELMAN, Shoshana. Jacques Lacan and the adventure of insight: Psychoanalysis in contemporary culture. Cambridge and London: Harvard University Press, 1987.

21 Tamtéž

22 Tamtéž 
něhož dochází k efektivnímu učení, tedy $\mathrm{k}$ takovému, při kterém se v dialogu konstruuje nové vědění a porozumění věci. ${ }^{23}$ Popisuje tak pedagogický přístup převažující nejen v prostředí muzeí a galerií, ale postupně prorůstající i do formální školní výuky, vycházející z konstruktivismu, jehož hlavní tezí je, že poznání neexistuje samo o sobě někde $\mathrm{v}$ éteru, ale vzniká během procesu učení a staví na prekonceptech učících se jedinců.

\section{Commemorative Museum Pedagogy jako možný přístup $\mathrm{k}$ difficult knowledge $\mathrm{v}$ muzejní expozici}

Julia Rose přichází s přístupem, který vychází z psychoanalytických aspektů zpracovávání těžkých témat v procesu učení. Nazývá jej Commemorative Museum Pedagogy [komemorativní muzejní edukace], a jeho hlavním cílem je poskytovat návštěvníkům citlivou a stálou podporu, která jim pomůže těžké téma zpracovávat dle jejich vlastního tempa a s ohledem na jejich vlastní kognitivní, poznávací a psychická specifika. ${ }^{24}$

\section{Rose tento přístup koncipovala} v roce 2006 ve své dizertační práci a původně jej zamýšlela jako návod pro muzejníky interpretující historii otroctví a život $v$ něm. Teoreticky jej opírá o koncept loss in learning, který byl popsán výše, a remembrance learning ${ }^{25}$ [výchova k uchování historické paměti] tedy o prrístup, který učí, jak tuto ztrátu kognitivně i psychicky zpracovat a přijmout. Jak vysvětluje Claudia

\section{Tamtéž}

24 ROSE, Julia. Commemorative Museum Pedagogy. In TROFANENKO, Brenda a Avner SEGALL (eds.). Beyond Pedagogy: Reconsidering the Public Purpose of Museums. Rotterdam: Sense Publisher, 2014, s. 115-133.

25 EPPERT, Claudia. Relearning questions: Responding to the ethical address of past and present others. In SIMON, Roger I., Sharon ROSENBERG a Claudia EPPERT (eds.). Between hope and despair: Pedagogy and the remembrance of historical trauma. Lanham: Rowman \& Littlefield Publishers, 2000, s. 213-246.
Eppert, výchova k uchování historické paměti vede ke komplexní přeměně jedince a jeho dosavadního způsobu nahlížení na život jako takový, nebot' mění jeho vnímání minulosti a transformuje jeho postojový a hodnotový systém. ${ }^{26}$

Klíčová slova remembrance ${ }^{27}$ a commemorative odkazují $\mathrm{k}$ aktu vzpomínání, vyjadřování úcty minulým generacím. Je to akt seznamování se s minulostí, jejího propojování s naší přítomností, hledání a uvědomování si souvislostí. Simon et al. pregnantně poznamenávají, že remembrance learning je v podstatě výchova etická, která pracuje s egem učících se jedinců a posouvá jeho hranice. ${ }^{28}$ Během aktu vzpomínání jsou jedinci konfrontováni s tragickými historickými událostmi, zpracovávají je a následkem toho revidují svou úlohu ve společnosti z pohledu historického, etického, existenciálního. Akt vzpomínání nám pomáhá přeměňovat naši budoucnost a rozšiřovat možnosti našeho vlastního učení a poznávání. ${ }^{29}$

Metodicky rozděluje Julia Rose proces osvojování těžkých témat v rámci komemorativní muzejní edukace do pěti fází, jejichž pořadí nemusí být zachováno. Následná charakteristika jednotlivých fází

\footnotetext{
26 Tamtéž.

27 V rámci Evropské unie můžeme zaznamenávat množství projektů zaměřujících se právě na výchovu k uchování historické paměti, jejímiž hlavními cíli jsou výchova k multikulturní společnosti, boj proti rasismu, rozvoj mediální gramotnosti a kritického myšlení apod. Realizovány byly např. projekty: The RETHINK project (Remembrance Education for THINKing critically); eCommemoration Project 'Europe 1945-2020: Looking Back, Thinking Forward'. Za Českou republiku je třeba zmínit především projekt Pamět národa, který vznikl z iniciativy neziskové organizace Post Bellum.

28 SIMON, Roger I., Sharon ROSENBERT a Claudia EPPERT (eds.). Between hope and despair: Pedagogy and the remembrance of historical trauma. Lanham: Rowman \& Littlefield Publishers, 2000. 29 Tamtéž.
}

volně interpretuje hlavní body popsané ve studii Julie Rose. ${ }^{30}$

Reception [recepce] je první fáze a popisuje počáteční kontakt muzejního návštěvníka s těžkým tématem. Motivace, která vedla k muzejní návštěvě, zůstává muzejním edukátorům $\mathrm{v}$ této chvíli utajena. Fáze recepce jim však poskytuje prostor pro prvotní oslovení návštěvníků a navození atmosféry výstavy, dává jim možnost upozornit návštěvníky na to, že téma výstavy pro ně může být znepokojující či kontroverzní. Průběh této fáze je determinován způsobem, jakým je prvotní kontakt s tématem koncipován a samotným zájmem návštěvníka o dané téma. ${ }^{31}$

Resistance tedy vzdorování novým informacím nastává, když prezentované informace či téma jako celek nejsou v souladu s poznávací strukturou návštěvníka a odporují jeho představě o morálním světě. Následkem toho návštěvník prožívá pocit ztráty své dosavadní představy o světě. Verbální a nonverbální projevy návštěvníka mohou signalizovat muzejním edukátorům probíhající krizi učení. Návštěvníci mají tendenci zpochybňovat nové informace, přistupovat $\mathrm{k}$ nim se skepsí a sarkasmem. Tato fáze procesu učení, kdy jedinec není schopen nové informace ihned přijmout a zpracovávat, mu dává zároveň příležitost $\mathrm{k}$ vnitřní přeměně, $\mathrm{k}$ přehodnocení svého dosavadního způsobu uchopování reality a světa kolem. Odmítání nových informací může být ukazatelem toho, že jej interpretace těžkého tématu zasahuje zcela novým, dosud nepoznaným způsobem. ${ }^{32}$

\footnotetext{
30 ROSE, Julia. Commemorative Museum Pedagogy. In TROFANENKO, Brenda a Avner SEGALL (eds.). Beyond Pedagogy: Reconsidering the Public Purpose of Museums. Rotterdam: Sense Publisher, 2014, s. 127-130.

31 Tamtéž, s. 127.

32 Tamtéž, s. 127-128.
} 
Repetition tedy repetice, vracení se k jednotlivým částem muzejní prezentace těžkého tématu je signálem toho, že návštěvník hledá způsob, jak těžké téma integrovat do své poznávací a psychické struktury. Návštěvník se snaží dané téma uchopovat po částech a jednotlivé segmenty informací a nových skutečností postupně zpracovávat, a tak si budovat nový obraz o světě. Jedná se o jednoznačný ukazatel toho, že návštěvník je aktivizován a motivován participovat v procesu osvojování těžkých témat. ${ }^{33}$

Reflection tedy reflexe je fáze, kdy návštěvník nové téma kognitivně zpracovává, napojuje jej na informace a zkušenosti získané během života, zasazuje novou interpretaci do již existujících vnitřních struktur, aktualizuje a vytváří ucelený obraz o světě. Návštěvník, který byl zprvu vyhnán ze své komfortní zóny, si nyní vytváří vztah k lidem, jejichž příběhy jsou prezentovány v expozici, představuje si jejich utrpení a vžívá se do jejich životů, dovolává se spravedlnosti. K reflexi potřebují návštěvníci dostatek času a prríležitostí například v podobě míst k odpočinku, k rozhovoru, ke kontemplaci. Rozhovor s muzejním pracovníkem v expozici může návštěvníkům pomoci těžké téma reflektovat do větší hloubky. ${ }^{34}$

Reconsideration [nový způsob uvažování o daném tématu] označuje fázi, ve které návštěvník dovršuje proces osvojení těžkého tématu. Nyní návštěvník uvažuje o tématu jinak a nově v kontextu přijatých a zpracovaných nových skutečností prezentovaných v muzejní expozici. Dochází k akomodaci nových informací, což se projevuje změněnými postoji návštěvníka, novým způsobem uvažování o tématu, empatickým

33 Tamtéž, s. 128.

34 Tamtéž, s. 129. cítěním s lidmi z těžkých př́íběhů, stejně tak jako zvýšeným zájmem dozvědět se o dané tematice více. Setkání s těžkým tématem, jeho přijetí a zpracování může návštěvníka natolik zasáhnout, že si expozici bude připomínat a v rozhovoru s jinými sdílet své zkušenosti z výstavy ještě dlouho poté. Významným projevem této fáze je nejen nové uvažování návštěvníka o konkrétním těžkém či kontroverzním tématu, ale jeho nové vnímání světa kolem $\mathrm{v}$ důsledku změněného poznávacího, postojového a hodnotového systému návštěvníka. ${ }^{35}$

O dekádu později Rose koncepci komemorativní muzejní edukace revidovala a nahlédla $v$ kontextu pokračujícího výzkumu a nových zkušeností. Právě na jejich základě definuje 5 klíčových faktorů, které podmiňují účinnost komemorativní muzejní edukace. Julia Rose doporučuje:

1. přijmout dané historické téma jako součást tragické historie provést kritické posouzení dopadu daných historických událostí na tehdejší jedince i celou tehdejší společnost a vyvodit důsledky, jež může dané téma mít pro společnost současnou;

2. brát ohledy na dynamiku výše zmíněných pěti fází komemorativní muzejní edukace - identifikovat krize učení u návštěvníků a posoudit jejich schopnost vyrovnat se se ztrátou jejich dosavadní představy o světě;

3. uplatňovat při interpretaci a prezentaci daného tématu tři základní stavební bloky tvář, skutečnost, příběh, které přispívají $\mathrm{k}$ vytváření etické muzejní prezentace a které

35 Tamtéž, s. 129-130. zdůrazňují lidskou stránku dané tragické historické události; provést kritické výzkumné šetření daného historického obsahu a identifikovat různé názorové postoje; definovat interpretační linii, ke které směřují příběhy prezentované v expozici;

4. zajistit bezpečné prostředí vhodné pro setkání s těžkými tématy a jejich následné zpracovávání, umožňující dialog a podporující návštěvníky v sebereflexi a sebeuvědomění zajistit emocionální podporu a ochranu návštěvníků, poskytnout prostředky pro zmírnění emočního šoku;

5. muzejním a galerijním institucím zacílit své aktivity na interpretaci a prezentaci těžkých témat, analyzovat je a zkoumat na základě upřímného zájmu $o$ věc, konat pro dobro společnosti a projevovat empatii nejen $\mathrm{k}$ jedincům a generacím minulým, ale i současným návštěvníkům ${ }^{36}$.

Na základě výše popsaných fází komemorativní muzejní edukace a následných doporučení lze vyvodit, že klíčové pro práci s těžkými tématy je přistupovat $\mathrm{k}$ jejich interpretaci a prezentaci obzvláště citlivě a se stálým zřetelem na utrpení a prožitá traumata představitelů historických př́běhů a na emocionální prožívání současných návštěvníků.

U první fáze, zaměřující se na počáteční kontakt návštěvníka s těžkým tématem, doporučuje Rose mimo jiné i verbální uvedení tématu muzejníkem. V současné muzejní kultuře však můžeme sledovat trend, kdy prvotní kontakt $s$ tématem zajištuje umělecké

36 ROSE, Julia. Interpreting Difficult History at Museums and Historic Sites. Maryland: Rowman \& Littlefield, 2016, s. 169-170. 
dílo. To má totiž moc dané těžké téma vizualizovat, vyprávět příběh, který se za ním skrývá, navodit celkovou atmosféru výstavy a vystihnout její hlavní interpretační linku. Má schopnost klást otázky a pobízet návštěvníky k hledání odpovědí. Často se může jednat o velice emotivní vizuální obraz, který se vryje do myslí návštěvníků a provází je po celou dobu návštěvy. Jako příklad můžeme uvést instalaci Nkyinkyim $^{37}$ (obr. 4) vytvořenou západoafrickým umělcem Kwame Akoto Bamfo a instalovanou u vstupu do areálu pomníku National Memorial for Peace and Justice věnovaného obětem rasové nespravedlnosti v USA. Pomník byl iniciován organizací Equal Justice Iniciative a oficiálně otevřen v roce 2018. Umělecké dílo odkazuje k otroctví a připomíná jeho klíčovou roli, kterou v šíření rasové nespravedlnosti tato temná část americké historie sehrála. ${ }^{38}$ Symbolem výstavy Hate Free? uvedené v roce 2016 v pražském Centru současného umění DOX se stala vstupní instalace (obr. 5) z dílny volného seskupení autonomů, aktivistů a umělců nesoucí název DE-FENCE. Dílo odkazuje k aktuální, avšak společnost silně polarizující, migrační otázce a $\mathrm{k}$ problematice detenčních táborů v ČR. Uvedené příklady ilustrují sílu uměleckého gesta symbolizovat těžké či kontroverzní téma a působit daleko za hranicemi umělecké sféry.

Proces identifikace návštěvníka s daným tématem usnadňuje dnes již velmi častá praxe narativní

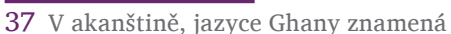
„kroucení“. Je to symbol představující klikatou a náročnou povahu životní cesty a schopnost člověka být nezlomný a vynalézavý. Symbolikon [online]. [2021-03-15]. Dostupné z: < https:// symbolikon.com/downloads/nkyinkyimadinkra/>.

38 The National Memorial for Peace and Justice [online]. [2021-03-15]. Dostupné z: <https://search. creativecommons.org/photos/6030b7de-8107-41c3a0f1-e5097d7a2e4e $>$.

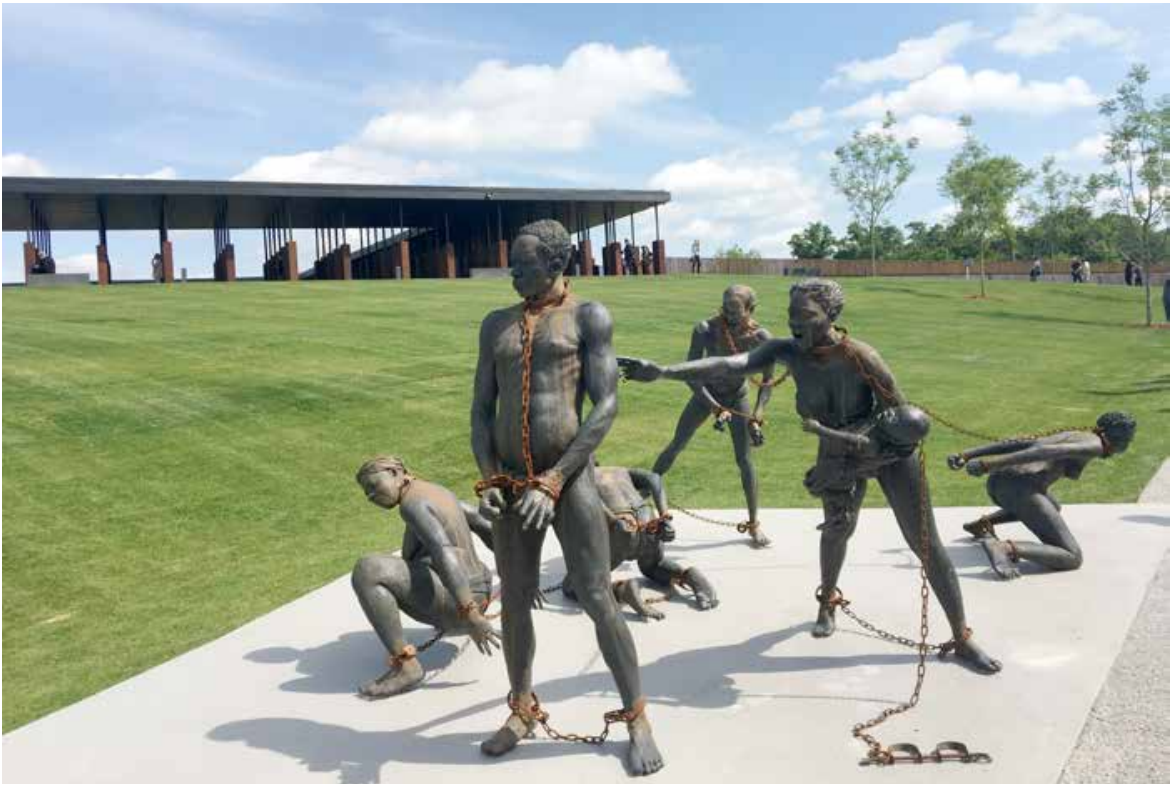

Obr. 4: Umělecké dílo instalované u vstupu do areálu pomníku National Memorial for Peace and Justice věnovaného obětem rasové nespravedlnosti v USA. Foto shawncalhoun - CC BY-NC 2.0.

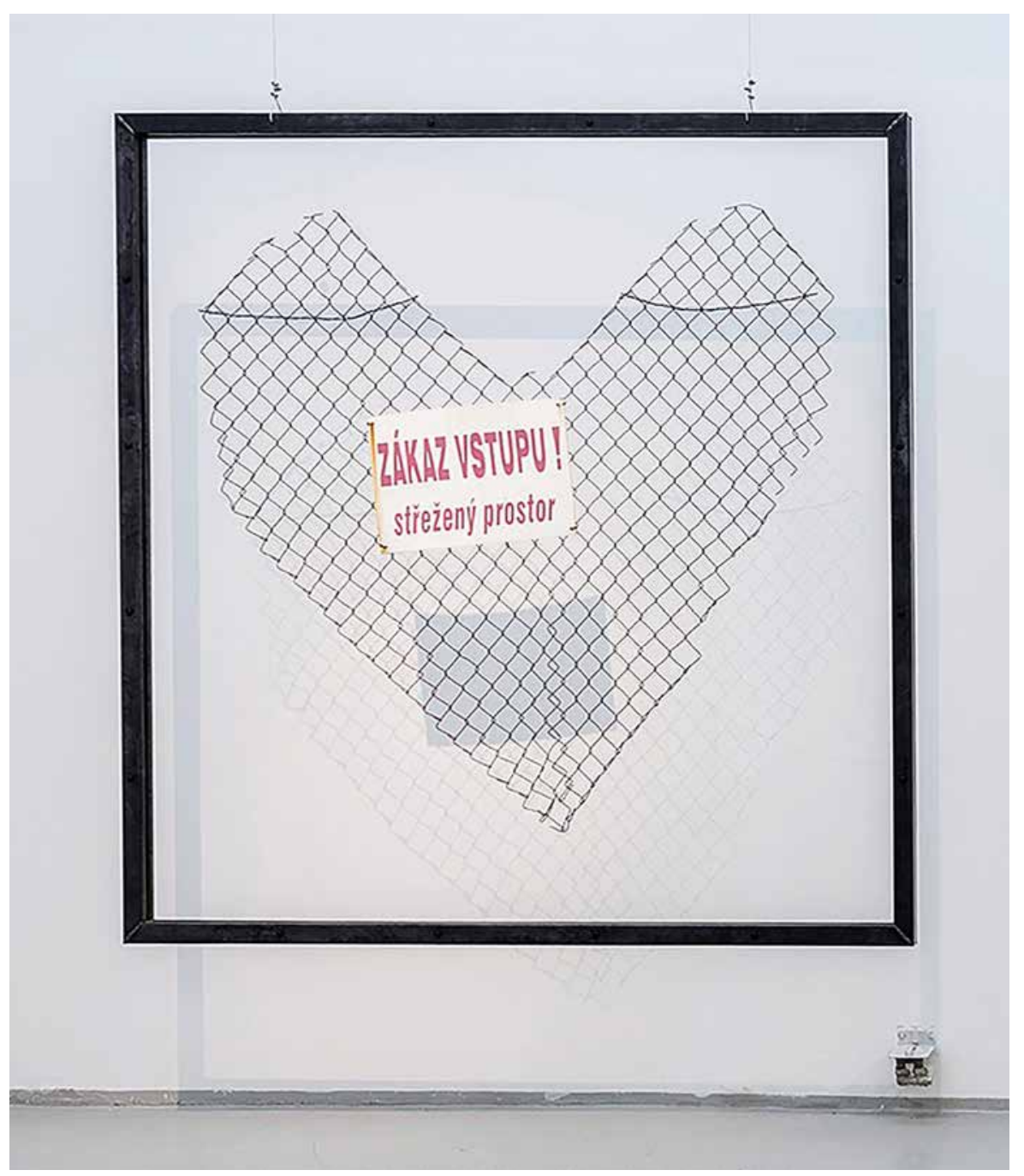

Obr. 5 Instalace u vstupu na výstavu Hate Free? symbolizující téma migrace a otázku detenčních táborů v ČR. Foto Zuzana Štefková. 
interpretace a prezentace daného tématu v prostředí muzeí a galerií. Téma prezentované prostřednictvím příběhu návštěvníkům připomíná, že jeho hlavními představiteli byli skuteční lidé žijící životy podobné jejich vlastním. Osoby tragických událostí tak mohou např́klad spadat do stejné věkové kategorie, pocházet ze stejného regionu či mít stejně staré děti. Mohou s návštěvníky sdílet stejný pohled na svět a řešit podobné problémy. Na základě vlastní identifikace $s$ př́iběhem se mohou návštěvníci snáze vcítit do životů daných osob a znovuprožívat popsané tragické historické události. Následkem toho pak přehodnocují své dosavadní vnímání světa, svou roli v něm a dané téma přijímají a integrují do stávající poznávací struktury. Pro zpřítomnění daného tématu je tedy důležité emocionálního náboje využít a zaměřit se na konkrétní příběhy jednotlivců či skupin lidí, avšak s důrazem na důstojnou a věrnou interpretaci jejich příběhu. Identifikace návštěvníka s daným jedincem a jeho traumatickým příběhem zvyšuje empatické vcítění a participaci návštěvníka na osvojení daného tématu. Těžké či kontroverzní téma lze návštěvníkům zpřítomnit i tím, že se $\mathrm{v}$ prostředí muzejní expozice pokusíme dané téma propojit $\mathrm{s}$ děním $\mathrm{v}$ současném světě, hledat $\mathrm{v}$ něm paralely $\mathrm{k}$ tragickým historickým událostem, vyvozovat $\mathrm{z}$ nich poučení a tím usilovat o to, aby nedošlo k jejich opakování.

Obzvláště u prezentace těžkých a kontroverzních témat je důležité vytvořit v expozici bezpečné prostředí pro nejrůznější projevy emočního prožívání a sdílení odlišných názorů. V expozici i v prostorách $\mathrm{v}$ její bezprostřední blízkosti by měly vzniknout tzv. klidové zóny umožňující návštěvníkům tichou kontemplaci nad tématem či dočasný odpočinek a uvolnění. Zároveň by měly být vytvořeny prŕiležitosti pro návštěvníky téma dále diskutovat, např́íklad v rámci pravidelných debatních kroužků či rozhovorů s muzejními pracovníky přímo v expozici. Hlavní interpretační linie těžkého či kontroverzního tématu by měla též reflektovat existenci odlišných pohledů na danou problematiku a tím otevírat a dále podporovat debatu např́č širokým názorovým spektrem. Muzejní a galerijní instituce by měly předem zmapovat názorovou různorodost $\mathrm{k}$ danému tématu, jež ve společnosti existuje a vytvořit podmínky pro konstruktivní a racionální debatu, ve které by mohly zaznít i marginalizované a protichůdné postoje. Právě tak se mohou muzejní a galerijní instituce stát součástí občanské společnosti, usilovat o překonávání existujících bariér ve společnosti, pomáhat představitelům rozdílných názorů nacházet společnou řeč a aktivně přispívat k sjednocení dané komunity a společnosti jako takové.

\section{Závěr}

Interpretovat a prezentovat těžká a kontroverzní témata $\mathrm{v}$ prostředí muzeí a galerií je důležité. Je to důležité nejen proto, že se tak tyto instituce etablují jako aktivní a aktuální součásti společenského dění a výchovy $\mathrm{k}$ demokratickému občanství, ale také proto, že tak vytvářejí př́ležitosti pro otevřený dialog, pro překonávání bariér a přispívají $\mathrm{k}$ sjednocení společnosti. V neposlední řadě tak mohou muzea a galerie kompenzovat často jednostranné a zavádějící způsoby, jakými jsou mnohá témata ve společnosti prezentována.

Vyjádřeno hesly Nezapomeňme!

a Nikdy více! jsou interpretace

a prezentace těžkých a kontroverzních témat $\mathrm{v}$ muzeích a galeriích důležité především proto, že nám dovolují vyjádřit svou účast a empatii lidem zasaženým těžkými událostmi, poskytují nám př́iležitost $s$ nimi znovu jejich utrpení a traumata prožívat a nedávat na ně zapomenout. Př́běhy interpretované a prezentované $\mathrm{v}$ muzejní expozici v nás, muzejních pracovnících a návštěvnících, často žijí dál a ovlivňují naše budoucí jednání, naše vnímání světa a přehodnocují naše morální vědomí i postojový a hodnotový systém. Těžká a kontroverzní témata nejen připomínají traumatické příběhy minulých generací, ale osvětově působí na generace budoucí, mají potenciál vést je $\mathrm{k}$ uvědomělému a zodpovědnému životu, k respektování lidských práv, sociální spravedlnosti a k mezilidskému a mezikulturnímu porozumění.

\section{POUŽITÁ LITERATURA:}

BARŠA, Pavel. Pamět a genocida: úvahy o politice holocaustu. Praha: Argo, 2011. ISBN 978-80-257-0368-7.

BRITZMAN, Deborah P. Lost subjects, contested objects: Toward a psychoanalytic inquiry of learning. Albany: State University of New York Press, 1998. ISBN 978-0-7914-3807-7.

BRITZMAN, Deborah P. If the story cannot end: deferred action, ambivalence and difficult knowledge. In SIMON, Roger I., Sharon ROSENBERG a Claudia EPPERT (eds.). Between hope and despair: Pedagogy and the remembrance of historical trauma. Lanham:

Rowman \& Littlefield Publishers, 2000, s. 27-56. ISBN 978-0847694631.

EPPERT, Claudia. Relearning questions: Responding to the ethical address of past and present others. In SIMON, Roger I., Sharon ROSENBERG a Claudia EPPERT (eds.). Between hope and despair: Pedagogy and the remembrance of historical trauma. Lanham: Rowman \& Littlefield Publishers, 2000, s. 213-246. ISBN 978-0847694631.

FELMAN, Shoshana. Jacques Lacan and the adventure of insight: Psychoanalysis in contemporary culture. Cambridge and London: Harvard University Press, 1987. ISBN 9780674471214. 
FINKELSTEIN, Norman G. Průmysl holocaustu: úvahy o zneužívání židovského utrpení. Praha: Dokořán, 2006. ISBN 80-7363-068-0.

FREUD, Sigmund. Spisy z let 1913-1917. Praha: Psychoanalytické nakladatelství, 2002. ISBN 80-86123-18-9.

GARRETT, James $H$. The routing and rerouting of difficult knowledge: Social studies teachers encounter. When the Levees Broke. Theory and Research in Social Education, 2011, roč. 39, č. 3, s. 320-347. ISSN 0093-3104. https://doi.org /10.1080/00933104.2011.10473458

HEYBACH, Jessica. A. Learning to feel what we see: Critical aesthetics and "difficult knowledge" in an age of war. Critical Questions in Education, 2012, roč. 3, č. 1, s. 23-34. ISSN 2327-3607.

JIROUTOVÁ, Jana. Muzeum 21. století a využití jeho soft power. In Muzeum a změna $V$. Praha: Asociace muzeí a galerií České republiky, z. s., 2017, s. 150-156. ISBN 978-80-86611-77-8.

LORD, Gail Dexter a Ngaire BLANKENBERG. Cities, museums and soft power. Washington, DC: American Alliance Of Museums, 2015. ISBN 978-1-941963-03-6. NOVICK, Peter. The Holocaust in American Life. Boston: Houghton Mifflin Company, 1999. ISBN 978-0618082322.

NYE, Joseph S. Soft power: the means to success in world politics. New York: PublicAffairs, 2004. ISBN 1-58648-306-4. PIAGET, Jean. Psychologie inteligence. Praha: Portál, 1999. ISBN 80-7178-309-9.

PITT, Alice J. Reading Resistance Analytically: On Making the Self in Women's Studies. In ROMAN Leslie G. a Linda EYRE (eds.). Dangerous Territories: Struggles for difference and equality in education. New York, London:
Routledge, 1997, s. 127-142. ISBN 9780415915960.

PITT, Alice J. a Deborah P. BRITZMAN. Speculations on qualities of difficult knowledge in teaching and learning: An experiment in psychoanalytic research. International Journal of Qualitative Studies in Education, 2003, roč. 16, č. 6, s. 755-776. ISSN 0951-8398. https://doi.org/ 10.1080/09518390310001632135

ROSE, Julia. Commemorative Museum Pedagogy. In TROFANENKO, Brenda a Avner SEGALL (eds.). Beyond Pedagogy: Reconsidering the Public Purpose of Museums. Rotterdam: Sense Publisher, 2014, s. 115-133. ISBN 978-94-6209-632-5.

https://doi.org/10.1007/978-94-6209-632-5_9 ROSE, Julia. Interpreting Difficult History at Museums and Historic Sites. Maryland: Rowman \& Littlefield Publishers, 2016. ISBN 9780759124370.

SIMON, Roger I., Sharon ROSENBERT a Claudia EPPERT (eds.). Between hope and despair: Pedagogy and the remembrance of historical trauma. Lanham: Rowman \& Littlefield Publishers, 2000. ISBN 978-0847694631.

Symbolikon [online]. [2021-03-15]. Dostupné z: <https://symbolikon.com/downloads/ nkyinkyim-adinkra/>.

The National Memorial for Peace and Justice [online]. [2021-03-15]. Dostupné z: $<$ https://search.creativecommons. org/photos/6030b7de-8107-41c3-a0f1e5097d7a2e4e $>$.

Život s kontroverzí. Výuka kontroverzních témat prostřednictvím výchovy k demokratickému občanství a lidským právům (EDC/HRE). Praha: Centrum občanského vzdělávání FHS UK, 2017.

\section{JANA JIROUTOVÁ}

Katedra výtvarné výchovy,

Pedagogická fakulta, Univerzita

Palackého v Olomouci, Česká republika

jana.jiroutova@upol.cz

Jana Jiroutová, M.Phil., Ph.D.

absolvovala doktorský studijní

program, obor Výtvarná výchova

(teorie výtvarné pedagogiky

a výtvarné tvorby) na katedře

výtvarné výchovy Pedagogické

fakulty Univerzity Palackého

v Olomouci. Ve svém výzkumu

se zaměřuje na historii muzejní

a galerijní pedagogiky v anglo-

americkém prostředí. Přednáší

muzeologii, dějiny muzejní kultury

a muzejní a galerijní pedagogiku.

Je členkou redakční rady časopisů

Výtvarná výchova a Kultura, umění

a výchova a od roku 2015 též

členkou výboru České sekce INSEA.

Jana Jiroutová, M.Phil., Ph.D.

has completed a doctoral

study program in the field of

Art Education (Theory of Art

Pedagogy and Art Production) at

the Department of Art Education,

Faculty of Education, Palacký

University Olomouc. In her

research, she focuses on the

history of museum and gallery

education in the Anglo-American

environment. She gives lectures

on museology, history of museum

culture and museum and gallery

education. She is a member of

the editorial board of the peer-

reviewed journals Výtvarná

výchova [Art Education] and

Kultura, umění a výchova [Culture,

Art and Education], and she has

been a member of the board of the

Czech Section of INSEA since 2015.

Toto dílo lze užít v souladu s licenčními podmínkami Creative Commons BY-SA 4.0 International (https://creativecommons.org/licenses/by-sa/4.0/ legalcode). Uvedené se nevztahuje na díla či prvky (např. obrazovou či fotografickou dokumentaci), které jsou v díle užity na základě smluvní licence nebo výjimky či omezení př́íslušných práv. 